Urban Agriculture and City Sustainability II 133

\title{
MEASUREMENT OF TECHNICAL EFFICIENCY: A CASE STUDY OF DAILOAN-MANGO IN VIETNAM
}

\author{
TRUONG HONG VO TUAN KIET ${ }^{1,2,3}$, NGUYEN THI KIM THOA ${ }^{1} \&$ PHAM THI NGUYEN ${ }^{4}$ \\ ${ }^{1}$ Mekong Delta Development Research Institute, Can Tho University, Vietnam \\ ${ }^{2}$ Southeast Asian Regional Center for Graduate Study and Research in Agriculture, Philippines \\ ${ }^{3}$ Institute of Agricultural and Food Policy Studies, Putra University, Malaysia \\ ${ }^{4}$ School of Economics, Can Tho University, Vietnam
}

\begin{abstract}
The findings of this study present the results of three producing seasons of DaiLoan-mango growers per year. The results showed that season 3 was the highest technical efficiency $(73.10 \%)$, the second place was season $1(62.65 \%)$, and then season $2(58.41 \%)$. Moreover, the independent variables that explained the technical efficiency of season 1 were the pesticide, root fertiliser, leaf fertiliser and labour; season 2 were the root fertiliser, leaf fertiliser and labour; and in season 3 were the pesticide, root fertiliser, leaf fertiliser, and labour. Besides this, the important determinants of socio-economic variables that impacted positively on technical efficiency were the land area in all three seasons, market access in season 2, and credit access in season 3. However, the constraints to DaiLoan-mango production were the farming experience in season 1, and the age in season 2. Based on these findings, policy makers should focus on effective input models that would boost technical efficiency through conducting regular workshops and orchard demonstrations on using input materials effectively for mango farmers. Moreover, farmers should be empowered in land area acquisition to apply advanced technology in large-scale production more effectively.
\end{abstract}

Keywords: DaiLoan-mango, technical efficiency, stochastic frontier.

\section{INTRODUCTION}

The king of the fruits, mango fruit, is one of the most popular fruits over the world, scientific name of mango is Mangifera Indica. Mangoes have traditionally been cultivated both in the sub-tropics and tropics. Vietnam provided mango volume approximately 836,000 tons in 2017 [1]. It ranked fourth in terms of mango volume in Southeast Asia after Thailand, Indonesia and Philippines and was top 15 the largest mango producers in the world. In Vietnam, mango is planted in most of all provinces, especially the southern Vietnam accounts for $75 \%$ of the mango production volume and for $72 \%$ of the mango production area [2].

The findings of Loc et al. [3] showed that gross income of mango farmers is an average of 186 million VND/ household/year, in which net income is 105.4 million VND, and average household cultivation area of 0.68 ha. Most of mango growers are small-scale; therefore, they confront with difficulties such as market signals relating to demand, varieties, quality and food safety, poor technical skills. Besides, mango producers must confront with uncertainly selling price, depending on collectors. In Vietnam, there are four prevalent mango varieties such as HoaLoc-mango, Chu-mango, Xiem-mango, and DaiLoan-mango, in which DaiLoan is considered new mango varieties, has been planted for 20 years, and become popular in 10 recent years. If HoaLoc, Chu, and Xiem mangoes were grown in rural areas, DaiLoan mango would be planted not only in remote places but also developed in urban region. One of main reasons is that DaiLoan-mango has adapted well various climate and soil conditions. Thus, households in cities choose DaiLoan-mango to grow as a kind of fruit and vegetables to provide fiber, sugar, protein, vitamin, calcium for their family (it can be eaten both raw and ripe fruit form). These are all extremely important nutrients for citizen's health. This type of fruit is not only delicious but also wonderful with delicious taste. That is reason why 
DaiLoan-mango is only mango varieties to become the most well-known fruit of households in urban areas in Vietnam. Particularly, it is suitable to produce small-scale with households level to apply smart farming system via hi-tech in context of agricultural urban development more and more to contribute diversity of nutritious supply sources to citizens towards food security at household level.

Hence, the objective of the paper was to identify determinants of technical efficiency in order to alleviate deferent constraints in the mango production as well as found out effective disparities in three mango production seasons. It helps both farmers in rural area and household in urban areas improve their farming procedure in order to obtain more effectively in production.

\section{MATERIALS AND METHODS}

\subsection{Sampling techniques}

Firstly, both south-eastern region and the Mekong Delta were chosen because these are the two biggest mango production in Vietnam, as it accounts for $75 \%$ of the mango production volume and for $72 \%$ of the mango production area in Vietnam. Secondly, Dong Nai province was chosen since it occupies approximately $55 \%$ of the mango production volume and $54 \%$ of the mango production area in south-eastern region. Thirdly, Dong Thap, An Giang, Tien Giang, Hau Giang, Vinh Long, and Tra Vinh provinces were selected because, combined, they make up approximately $77 \%$ of the mango production volume and $71 \%$ of the mango production area in Mekong Delta [2]. Finally, a simple random sampling technique was used to select 732 sample observations (239, 249, and 244 for seasons 1, 2, and 3, respectively). Data collection was investigated from August to October 2018.

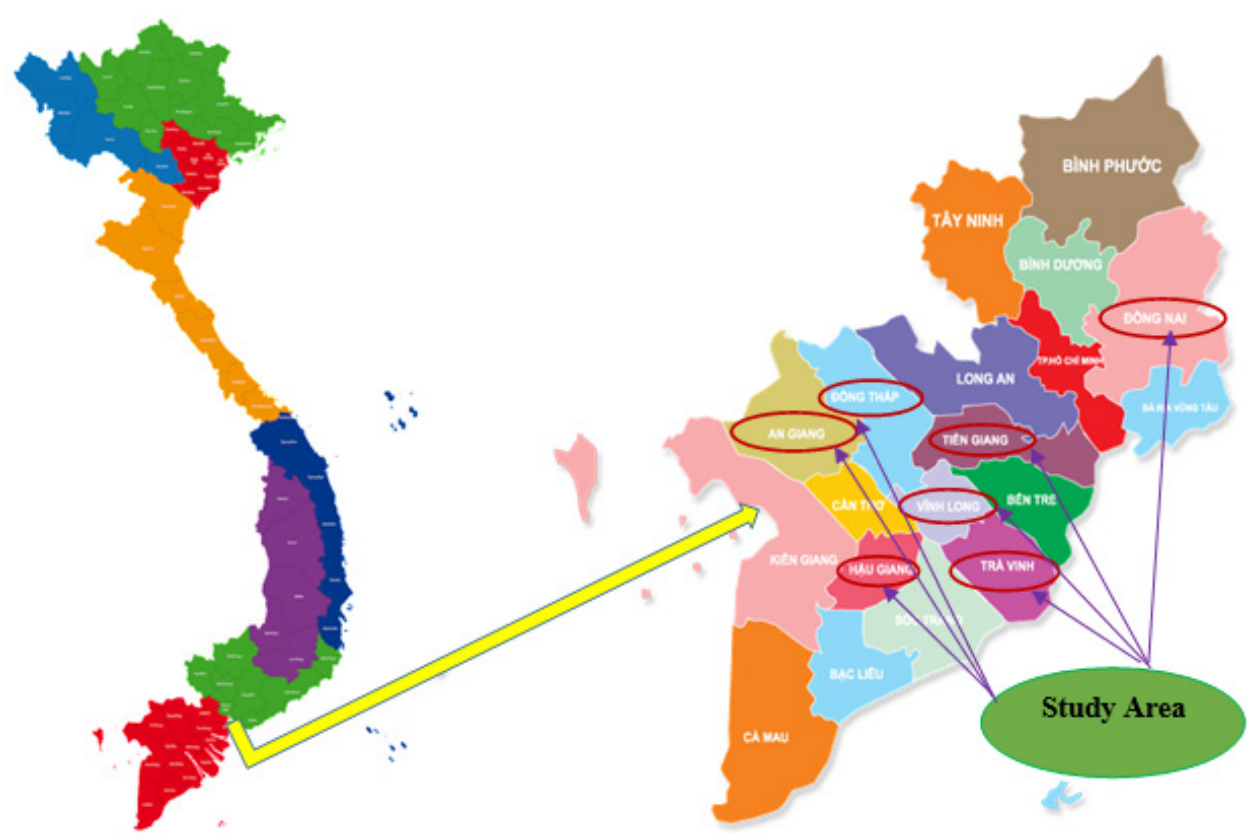

Figure 1: Study area in the southern Vietnam. 


\subsection{Theoretical model}

Technical efficiency (TE) is the capacity of a production unit to produce a maximum level of output at the same level of inputs, or to produce a given output with minimal inputs [4], [5]. By contrast, Battese and Corra [6] claim that technical inefficiency increases when observed output is produced form given inputs to obtain less than capacity of the maximum probable. The difference in technical efficiency among farmers may be related to the manager's decision, environmental conditions (land area, rainfall, temperature and soil relative humidity), and non-technical and non-economic elements, and household characteristics that may affect a farmer's ability to use technology [7].

The measurement of farm efficiency is vital, especially for farmers in developing countries [8]. Overall, the factors that affect farmers' efficiency could be grouped into agent and structural factors. Agent factors are those linked to the farm manager, such as the educational level, family size, age, and social capital. These factors are categorised into farmspecific variables (intensity of inputs such as labour, fertilisers, and seeds), economic factors (input and output prices), and environmental factors (rain, relative humidity, and temperature).

According to Aigner et al. [9] the formulation of a stochastic frontier model in the production function could be presented as:

$$
\mathrm{Y}_{\mathrm{i}}=\mathrm{f}\left(\mathrm{X}_{\mathrm{i}}, \beta\right) \varepsilon_{\mathrm{I}},
$$

with:

$$
\varepsilon_{\mathrm{i}}=\mathrm{V}_{\mathrm{i}}-\mathrm{U}_{\mathrm{i}},
$$

where:

$\mathrm{Y}_{\mathrm{i}}$ is output of the $i$-th farmers;

$\mathrm{f}\left(\mathrm{X}_{\mathrm{i}}, \beta\right)$ is an appropriate functional form;

$\beta$ is a vector parameters to be estimated;

$\varepsilon_{\mathrm{i}}$ is composite error term;

$\mathrm{V}_{\mathrm{i}}$ denotes the random error not under the control of the farmers, associated with random factors outside the farmer's control; and

$\mathrm{U}_{\mathrm{i}}$ is the non-negative random variable associated with technical inefficiency and is identically and independently distributed as a truncated normal, with truncations at zero of the normal distribution.

The technical efficiency of the farmer is:

$$
\text { Technical efficiency }(T E)=Y i / Y_{i}^{*} \text {, }
$$

where $Y i$ is the observed output and $\mathrm{Y}_{i}^{*}$ is the frontier output.

$$
\mathrm{TE}=\mathrm{f}\left(\mathrm{X}_{\mathrm{i}}, \beta\right) \exp \left(\mathrm{V}_{\mathrm{i}}-\mathrm{U}_{\mathrm{i}}\right) / \mathrm{f}\left(\mathrm{X}_{\mathrm{i}}, \beta\right) \exp \left(\mathrm{V}_{\mathrm{i}}\right)=\exp \left(-\mathrm{U}_{\mathrm{i}}\right)
$$

this is such that $0 \leq \mathrm{TE}_{\mathrm{i}} \leq 1$.

In this case, this measure raged from zero to one, and it was used to evaluate evaluated the output of the $i$-th farm relative to the output of a fully efficient farm or a best practice farm using the same vector of inputs. The first step in predicting the technical efficiency according to Coelli et al. [10] is to the estimate the parameters of the stochastic production frontier. This has often taken place using the maximum likelihood estimates, which use the ordinary least squares (OLS) results as a starting point. However, the MLE are preferred over the corrected ordinary least squares (COLS) method because they have many desirable large 
sample (i.e. asymptotic) properties [10]. Aigner et al. [9] obtained MLE under the assumptions that

$$
\boldsymbol{v} \boldsymbol{i} \sim\left(\mathbf{0}, \boldsymbol{\sigma} \boldsymbol{v}^{2}\right),
$$

and

$$
\boldsymbol{u} \boldsymbol{i} \sim \boldsymbol{i i d N}+\left(\mathbf{0}, \boldsymbol{\sigma u ^ { 2 } )} .\right.
$$

In the aforementioned equations, the $v$ are independently and identically distributed, normal random variables with zero means and the variances $\sigma v^{2}$ and, $u i$ are independently and identically distributed, half-normal random variables with scale parameter $\sigma i 2$. Coelli et al. [10] suggested that the finding of Battese and Corra [6] who parameterised the loglikelihood in terms of $\sigma^{2}$ and $\gamma=\sigma u^{2} / \sigma^{2}$, is the most appealing because if $\gamma=0$ then all deviations from the frontier are due to statistical noise, while $\gamma=1$ suggests that all deviations are due to technical efficiency.

\subsection{Stochastic production function model}

A Cobb-Douglas production function was adopted. Despite its well-known limitation, the Cobb-Douglas functional form was used. The stochastic frontier model was defined by:

$$
\ln \mathrm{Y} i=\beta \mathrm{o}+\beta 1 \ln \mathrm{X} 1+\beta 2 \ln \mathrm{X} 2+\beta 3 \ln \mathrm{X} 3+\beta 4 \ln \mathrm{X} 4+\beta 5 \ln \mathrm{X} 5+V i-U i,
$$

where:

$\ln =$ Logarithm to base e;

$Y i=$ Mango output $(\mathrm{kg})$;

$\beta \mathrm{o}=$ Constant or Intercept of the model;

$\beta 1-\beta 5=$ Coefficients to be estimated;

$\mathrm{X} 1=$ Pesticide quantity (litres);

$\mathrm{X} 2$ = Fungicide quantity (litres);

$\mathrm{X} 3=$ Root fertiliser quantity $(\mathrm{kg})$;

$\mathrm{X} 4$ = Leaf fertiliser quantity $(\mathrm{kg})$ (sprayed on mango leaves to induce flowering in mango trees);

X5 = Family and hired labour (man-days);

$V i=$ Random error term; and

$U i=$ Technical efficiency effect predicted by the model and the subscript $i$ indicate the $i$-th farmer in the sample.

The inefficiency model based on Ogunniyi [11] was specified as

$$
u_{i}=\alpha_{0}+\sum_{r=1}^{10} \alpha_{r} Z_{r}+\mathbf{k}
$$

where:

$\boldsymbol{u}_{\boldsymbol{i}}=$ technical efficiency of $i$-th farmer;

$\alpha_{0}$ and $\alpha_{r}=$ parameters to be estimated;

$\mathrm{k}=$ Truncated random variable;

$\mathrm{Z}_{1}=$ age (year);

$\mathrm{Z}_{2}=$ Education;

$\mathrm{Z}_{3}=$ Farming experience (year);

$Z_{4}=$ Credit accessibility level (access $=1$, no access $=0$ );

$Z_{5}=$ Payment of agro-inputs for wholesaler (ending of crop $=1$, immediate payment $=0$ );

$\mathrm{Z}_{6}=$ Wrapping bag (wrap $=1$, no wrap $\left.=0\right)$ (applied mango wrap technique against incursion of pest, insect); 
$\mathrm{Z}_{7}=$ Market accessibility level (access $=1$, no access $=0$ );

$\mathrm{Z}_{8}=$ Classifying sale (classification $=1$, no classification $=0$ ) (selling mango is classified including: first level with best price, second level with medium price, and third level with lowest price); and $\mathrm{Z}_{9}=$ Land area $\left(\right.$ cong $\left.=1,000 \mathrm{~m}^{2}\right)$.

The analysis of study is carried out by maximising likelihood estimation (MLE) on the STATA15.0 programme.

\section{RESULTS AND DISCUSSION}

\subsection{Estimation procedure}

The result of the MLE were presented in Table 1. The variance ratio parameter $(\gamma)$ was statistically greater than zero and equal $0.6124 ; 0.6601$ and 0.5853 for seasons 1,2 and 3

Table 1: Maximum likelihood estimates of the stochastic production function. (Source: Field Survey Data, 2018.)

\begin{tabular}{|c|c|c|c|c|c|c|}
\hline \multirow{2}{*}{ Variables } & \multicolumn{2}{|c|}{ Season 1} & \multicolumn{2}{|c|}{ Season 2} & \multicolumn{2}{|c|}{ Season 3} \\
\hline & Coef. & SE & Coef. & SE & Coef. & SE \\
\hline \multicolumn{7}{|l|}{ (Y): Ln yield (kg) } \\
\hline Constant & $5.2212 * * *$ & 0.3934 & $6.3316^{* * *}$ & 0.3717 & $6.7366^{* * *}$ & 0.7461 \\
\hline $\begin{array}{l}\left(\mathrm{X}_{1}\right) \text { Ln pesticide } \\
\text { (liters) }\end{array}$ & $0.1424 * * *$ & 0.0450 & 0.1579 & 0.0510 & $0.2054 * * *$ & 0.0508 \\
\hline $\begin{array}{l}\left(\mathrm{X}_{2}\right) \text { Ln fungicide } \\
\text { (liters) }\end{array}$ & 0.0047 & 0.0473 & 0.0943 & 0.0599 & -0.0157 & 0.0502 \\
\hline $\begin{array}{l}\left(\mathrm{X}_{3}\right) \text { Ln root fertiliser } \\
(\mathrm{kg})\end{array}$ & $0.1328 * * *$ & 0.0518 & $-0.0515 * * *$ & 0.0451 & $0.0805^{* *}$ & 0.0334 \\
\hline $\begin{array}{l}\left(\mathrm{X}_{4}\right) \text { Ln leaf fertiliser } \\
(\mathrm{kg})\end{array}$ & $0.2841 * * *$ & 0.0702 & $0.3316^{* * *}$ & 0.0601 & $0.1008 * *$ & 0.0420 \\
\hline $\begin{array}{l}\left(\mathrm{X}_{5}\right) \text { Ln labour (man } \\
\text { day) }\end{array}$ & $0.3312 * * *$ & 0.0795 & $0.2550^{* * *}$ & 0.0945 & $0.1883 * * *$ & 0.0675 \\
\hline \multicolumn{7}{|l|}{ Diagnostic statistics } \\
\hline Prob $>\chi^{2}$ & 0.0000 & & 0.0000 & & 0.0000 & \\
\hline Sigma square $\left(\sigma^{2}\right)$ & 1.2568 & & 1.2260 & & 1.0432 & \\
\hline Lamda $(\lambda)$ & 1.0735 & & 1.0441 & & 0.5323 & \\
\hline Sigma_v $\left(\sigma_{v}\right)$ & 0.6979 & & 0.6455 & & 0.6577 & \\
\hline Sigma_u $\left(\sigma_{u}\right)$ & 0.8773 & & 0.8996 & & 0.7814 & \\
\hline $\operatorname{Gamma}(\gamma)$ & 0.6124 & & 0.6601 & & 0.5853 & \\
\hline Log-likelihood function & -270.31 & & -327.87 & & -306.91 & \\
\hline Number of obs $(\mathrm{N})$ & 239 & & 249 & & 244 & \\
\hline
\end{tabular}

Parameter gamma $\gamma=\sigma_{\mathrm{u}}{ }^{2} /\left(\sigma_{\mathrm{u}}{ }^{2}+\sigma_{\mathrm{v}}{ }^{2}\right)$. Sigma square $\sigma^{2}=\sigma_{\mathrm{u}}{ }^{2}+\sigma_{\mathrm{v}}{ }^{2}$.

* Significant at the $10 \%$ level, $* *$ significant at the $5 \%$ level, $* * *$ significant at the $1 \%$ level. 
respectively, thereby suggesting that $61.24 \%, 66.01 \%$, and $58.53 \%$ of variation in seasons 1 , 2 and 3 respectively, which caused TE of the sampled growers rather than random variability.

In the first season, the result showed that the coefficients of the pesticide, root fertiliser, leaf fertiliser and labour were positive and statistically significant at the $1 \%$ level. The positive relationship with yield proposed that a $10 \%$ increase in the pesticide, root fertiliser, leaf fertiliser and labour would result in $1.424 \%, 1.328 \%, 2.841 \%$ and $3.312 \%$ respectively, improvement in yield of DaiLoan-mango farmers.

In season 2, there were positively signed and significant in the coefficients of the leaf fertiliser, and labour at the $1 \%$ significance level, thus rising $10 \%$ of these variables would increase yield of DaiLoan-mango in 3.316\%, and 2.550\%, respectively. Meanwhile, the root fertiliser variable was negative effect on DaiLoan-mango yield at the $1 \%$ significance level. It meant that a $10 \%$ gain in root fertiliser quantity would decrease $0.515 \%$ of DaiLoan-mango yield.

In season 3, the results demonstrated that the coefficient explanatory variables of the pesticide, and labour in the stochastic production function were positively significant at the $1 \%$ level, and the root fertiliser, and leaf fertiliser were significant at the $5 \%$ level, thereby implying that a $10 \%$ increase in the pesticide, root fertiliser, leaf fertiliser, and labour would lead to $2.054 \%, 0.805 \%, 1.008 \%$ and $1.883 \%$ increase in mango yield for DaiLoan-mango growers, respectively.

\subsection{Analysis of technical efficiency}

Table 2 shows the elements influencing TE of DaiLoan-mango gardeners in Vietnam in all three seasons. The aim of estimating to identify the relationship between TE and socioeconomic characteristics.

Table 2: Estimated technical efficiency values. (Source: Field Survey Data, 2018.)

\begin{tabular}{|l|c|c|c|c|c|c|}
\hline \multirow{2}{*}{ Variable } & \multicolumn{2}{|c|}{ Season 1 } & \multicolumn{2}{c|}{ Season 2 } & \multicolumn{2}{c|}{ Season 3 } \\
\cline { 2 - 7 } & Coef. & SE & Coef. & SE & Coef. & SE \\
\hline Constant & $0.5937 * * *$ & 0.0497 & $0.5580^{* * *}$ & 0.0500 & $0.6978^{* * *}$ & 0.0228 \\
\hline Age (Z1) & -0.0004 & 0.0006 & $-0.0011^{*}$ & 0.0007 & -0.0001 & 0.0002 \\
\hline Education (Z2) & 0.0026 & 0.0021 & 0.0010 & 0.0022 & 0.0012 & 0.0009 \\
\hline Farming experience (Z3) & $-0.0017 *$ & 0.0010 & 0.0003 & 0.0010 & 0.0003 & 0.0004 \\
\hline Credit access (Z4) & -0.0063 & 0.0177 & -0.0253 & 0.0182 & $0.0163 * *$ & 0.0073 \\
\hline $\begin{array}{l}\text { Payment for agro-input } \\
\text { Z5) }\end{array}$ & -0.0183 & 0.0155 & 0.0033 & 0.0162 & 0.0007 & 0.0068 \\
\hline Wrapping bag (Z6) & 0.0051 & 0.0180 & 0.0089 & 0.0185 & 0.0061 & 0.0079 \\
\hline Market access (Z7) & -0.0115 & 0.0195 & $0.0437 * *$ & 0.0194 & 0.0046 & 0.0090 \\
\hline Classifying sale (Z8) & 0.0154 & 0.0165 & -0.0090 & 0.0163 & 0.0036 & 0.0074 \\
\hline Land area (Z9) & $0.0033 * * *$ & 0.0009 & $0.0048 * * *$ & 0.0009 & $0.0013 * * *$ & 0.0003 \\
\hline
\end{tabular}

* Significant at the $10 \%$ level, ${ }^{* *}$ significant at the $5 \%$ level, ${ }^{* * *}$ significant at the $1 \%$ level.

In the first season, the farming experience variable was negative influence on technical efficiency of DaiLoan-mango producers at the 5\% significance level. This indicated that if producers rise farming experience in $10 \%$, mango yield would decline in $0.017 \%$. The result was against with some earlier researches [12]-[14]. The studies stated a positive relationship between technical efficiency and farming experience. 
In the second season, the age variable was negative and significant effect on farmers' technical efficiency at the $10 \%$ level contrasting with being positive influence of the market access variable at the $5 \%$ probability level. The finding of age was a significant result for younger farmers were relatively more efficient than older farmers. The result was in conformity with the studies of [15]-[20]. However, the information was disagreement with some previous researches [12], [21].

In the third season, the credit access variable was positive influence on technical efficiency of DaiLoan-mango growers at the 5\% significance level. The result of credit access was similar with previous studies of Kiet and Thoa [20], Bifarin et al. [22] and Khan and Ali [23] who found a strong and positive relationship between credit access and technical efficiency of the farmer, but it was different from past result of Khan and Saeed [5], Daniel [18] and Khan and Ali [23].

Particularly, the land area variable had positive coefficients and highly significant at the $1 \%$ in all three seasons at the conventional significance levels. Similar findings were obtained by Maria [12], Kiet and Thoa [20], Obare et al. [24] and Dorward [25]. However, this went against the results of Adbur [15] and Daniel [18].

\subsection{Estimating the distribution of technical efficiency}

The research indicated that technical efficiency was between 0.2044 and 0.8387 , and a mean TE was 0.6265 in the season 1 . Next, TE of the season 2 was from 0.1039 to 0.8342 with a mean of 0.5841 . In season 3 , TE ranged from 0.5616 to 0.8252 , and achieved a mean TE 0.7310 . The finding suggested TE gap of approximately $37.35 \%, 41.59 \%$ and $26.90 \%$ in seasons 1, 2 and 3 respectively, thereby implying that an average mango farmer in Vietnam had the capacity to rise technical efficiency in mango production by $37.35 \%, 41.59 \%$, and $26.90 \%$ in seasons 1,2 , and 3 to obtain the maximum possible level.

Table 3: Frequency distribution of technical efficiency. (Source: Field Survey Data, 2018.)

\begin{tabular}{|c|c|c|c|c|c|c|}
\hline \multirow{2}{*}{$\begin{array}{c}\text { Technical } \\
\text { efficiency } \\
\text { level }\end{array}$} & \multicolumn{2}{|c|}{ Season 1} & \multicolumn{2}{|c|}{ Season 2} & \multicolumn{2}{|c|}{ Season 3} \\
\hline & Frequency & Percentage & Frequency & Percentage & Frequency & Percentage \\
\hline$<0.1$ & 0 & 0.00 & 0 & 0.00 & 0 & 0.00 \\
\hline $0.1-<0.2$ & 0 & 0.00 & 1 & 0.40 & 0 & 0.00 \\
\hline $0.2-<0.3$ & 1 & 0.42 & 2 & 0.80 & 0 & 0.00 \\
\hline $0.3-<0.4$ & 8 & 3.35 & 20 & 8.03 & 0 & 0.00 \\
\hline $0.4-<0.5$ & 25 & 10.46 & 30 & 12.05 & 0 & 0.00 \\
\hline $0.5-<0.6$ & 64 & 26.78 & 78 & 31.33 & 3 & 1.23 \\
\hline $0.6-<0.7$ & 66 & 27.62 & 76 & 30.52 & 56 & 22.95 \\
\hline $0.7-<0.8$ & 69 & 28.87 & 41 & 16.47 & 169 & 69.26 \\
\hline $0.8-<0.9$ & 6 & 2.51 & 1 & 0.40 & 16 & 6.56 \\
\hline $0.9-<1.0$ & 0 & 0.00 & 0 & 0.00 & 0 & 0.00 \\
\hline 1.0 & 0 & 0 & 0 & 0 & 0 & 0 \\
\hline Obs (N) & \multicolumn{2}{|c|}{239} & \multicolumn{2}{|c|}{249} & \multicolumn{2}{|c|}{244} \\
\hline Minimum & \multicolumn{2}{|c|}{0.2044} & \multicolumn{2}{|c|}{0.1039} & \multicolumn{2}{|c|}{0.5616} \\
\hline Maximum & \multicolumn{2}{|c|}{0.8387} & \multicolumn{2}{|c|}{0.8342} & \multicolumn{2}{|c|}{0.8252} \\
\hline Mean & \multicolumn{2}{|c|}{0.6265} & \multicolumn{2}{|c|}{0.5841} & \multicolumn{2}{|c|}{0.7310} \\
\hline $\begin{array}{l}\text { Standard } \\
\text { deviation }\end{array}$ & \multicolumn{2}{|c|}{0.1156} & \multicolumn{2}{|c|}{0.1184} & \multicolumn{2}{|c|}{0.0518} \\
\hline
\end{tabular}


The sample frequency distribution showed that there were TE gap but with scope for enhancement in mango farming among mango farmers. The implication of the result was that the average mango grower required $25.30 \%$ [(1-0.6265/0.8387)*100] in season $1,29.98 \%$ $\left[(1-0.5841 / 0.8342)^{*} 100\right]$ in season 2 and $11.42 \%\left[(1-0.7310 / 0.8252)^{*} 100\right]$ in the second season cost saving to attain the status of the most efficient mango gardeners in Vietnam, while the least efficient gardeners proposed an enhancement in technical efficiency of $75.63 \%\left[(1-0.2044 / 0.8387)^{*} 100\right]$ in season $1,87.54 \%\left[(1-0.1039 / 0.8342)^{*} 100\right]$ in season 2 , and $31.94 \%\left[(1-0.5616 / 0.8252)^{*} 100\right]$ respectively.

\section{CONCLUSIONS}

The result of analysis presented that season 3 was the highest technical efficiency $73.10 \%$, the second place was season 1 approximately $62.65 \%$, and then season 2 was $58.41 \%$. This suggested that gardeners would increase their farming on average via $73.10 \%, 62.65 \%$ and $58.41 \%$ respectively.

In addition, the findings indicated that adjustments in input factors could help to improved production of DaiLoan-mango in Vietnam. More specific, the independent variables that played major role in determining yield in the first season were the pesticide, root fertiliser, leaf fertiliser, and labour, in season 2 were the root fertiliser, leaf fertiliser, and labour, and in season 3 were the pesticide, root fertiliser, leaf fertiliser and labour.

Eventually, the result showed that the positive determinants of TE were the land area in all three seasons, the market access in the second season, and the credit access in the third season. However, the constraints to DaiLoan-mango production were the farming experience in the first season, and the age and in the second season.

\section{ACKNOWLEDGEMENTS}

The study used data source from project "Value chain development of Vietnamese mango fulfilling requirement for domestic and international markets" (2017-2020, code: KHCNTNB.ĐT/14-19/C14). We would like to thank the financial support from program "Technology and science program for sustainable development in south-western region" from the Ministry of Technology and Science in Vietnam. Thanks for coordination from Professor Tran Van Hau (project leader) from school of Agriculture, Can Tho University.

\section{REFERENCES}

[1] FAO, Major Tropical Fruits: Statistical Compendium 2017, FAO: Rome, 38 pp., 2019.

[2] General Statistic Office of Vietnam (GSO), Statistical Year Book 2017, Statistical Publishing House, Vietnam, 2018.

[3] Loc, V.T.T., Kiet, T.H.V.T., Son, N.P., An, N.T.T., Tin, N.H., Tho, T.H. \& Huon, L., Analysis of mango value chain in Dong Thap province. Mekong Delta Development Research Institute, Can Tho University, Vietnam, 2014.

[4] Farrell, M.J., The measurement of productive efficiency. Journal of the Royal Statistical Society, Series A, pp. 253-281, 1957.

[5] Khan, H. \& Saeed, H., Measurement of technical, allocative and economic efficiency of tomato farms in northern Pakistan. International Conference on Management, Economics and Social Sciences (ICMESS 2011), Bangkok, 2011.

[6] Battese, G. \& Corra, G., Estimation of a production frontier model with the application of the pastoral zone of Easter Australia. Australian Journal of Agricultural Economics, 21(3), pp. 167-179, 1977.

[7] Amaza, P.S. \& Olayemi, J.K., Technical efficiency in food crop production Gombe State, Nigeria, The Nigeria Agricultural Journal, 32(2), pp. 140-151, 2001. 
[8] Ume, S.I., Ezeano, C.I., Chukwuigwe, O. \& Gbughemobi, B.O., Resource use and technical efficiency of okra production among female headed household: Implication for poverty alleviation in the rural areas of south east, Nigeria. International Journal of Advanced Research and Development, 5(24), 2018.

[9] Aigner, D.K., Lovell, C.K. \& Schmidt, P., Formulation and estimation of stochastic frontier production function models. Journal of Econometrics, 6, pp. 21-37, 1977.

[10] Coelli, T.J., Prasada Rao, D.S., O’Donnell, C.J. \& Battese, G.E., An Introduction to Productivity and Efficiency Analysis, 2nd ed., Springer: New York, USA, pp. 214222, 2005.

[11] Ogunniyi, L.T., Profit efficiency among maize producers in Oyo State, Nigeria. ARPN Journal of Agricultural and Biological Science, 6, pp. 11-17, 2011.

[12] Maria, S.M., Analysing the technical and allocative efficiency of small-scale maize farmers in Tzaneen municipality of Mopani district: A Cobb-Douglas and logistic regression approach. Master's thesis of Agricultural Management (Agricultural Economics), Department of Agricultural Economics and Animal Production, Faculty of Science and Agriculture School of Agricultural and Environmental Sciences at the University of Limpopo, 2015.

[13] Abdukadir, S., Analysis of technical efficiency of groundnut production: the case of smallholder farmers in Harari region. MSc thesis presented to the School of Graduate Studies of Haramaya University, 2010.

[14] Dadzie, S.K.N. \& Dasmani, I., Gender difference and farm level efficiency: Metafrontier production function approach. Journal of Development and Agricultural Economics, 2, pp. 441-451, 2010.

[15] Abdur, R.S.M., A study on economic efficiency and sustainability of wheat production in selected areas of Dinajpur District. MSc thesis, Bangladesh Agricultural University, 2012.

[16] Alam, A., Kobayashi, H., Motsumura, I., Ishida, A. \& Esham, M., Technical efficiency and its determinants in potato production: Evidence from northern areas in GilgitBaltistan region. International Journal of Research in Management, Economics and Commerce, 2, pp. 1-17, 2012.

[17] Bealu, T., Endrias, G. \& Tadesse, A., Factors affecting economic efficiency in maize production: The case of Boricha Woreda in Sidama Zone, Southern Ethiopia. The 4th Regional Conference of the Southern Nationalities State Economic Development in Hawassa, 28 pp., 2013.

[18] Daniel, H.G., Analysis of economic efficiency in potato production: The case of smallholder farmers in Welmera district, Oromia special zone, Oromia, Ethiopia. MA thesis in Development Economics, Department of Economics, College of Business and Economics, School of Graduate Studies, Hawassa University, 2016.

[19] Sibiko, K.W., Mwangi, J.K., Gido, E.O., Ingasia, O.A. \& Mutai, B.K., Allocative efficiency of smallholder common bean producers in Uganda. International Journal of Development and Sustainability, 2(2), pp. 640-652, 2013.

[20] Kiet, T.H.V.T. \& Thoa, N.T.K., Technical efficiency of mango in Vietnam. International Journal of Advanced Science and Technology, 29(11), pp. 748-755, 2020.

[21] Malinga, N.G., Masuku, M.B. \& Raufu, M.O., Comparative analysis of technical efficiencies of smallholder vegetable farmers with and without credit access in Swazil and the case of the Hhohho region. International Journal of Sustainable Agricultural Research, 2(4), pp. 133-145, 2015. 
[22] Bifarin, J.O., Alimi, T., Baruwa, O.I. \& Ajewole, O.C., Determinants of technical, allocative and economic efficiencies in the plantain (Musa spp.) production industry, Ondo State, Nigeria. Federal College of Agriculture, Ondo State, Nigeria, 2010.

[23] Khan, H. \& Ali, F., Measurement of productive efficiency of tomato growers in Peshawar, Pakistan. Agric. Econ. Czech., 8, pp. 381-388, 2013.

[24] Obare, G.A., Daniel, O.N. \& Samuel, M., Are Kenyan smallholders allocatively efficient? Evidence from Irish potato producers in Nyandarua North district. Journal of Development and Agricultural Economics, 2(3), pp. 78-85, 2010.

[25] Dorward, A., Farm size and productivity in Malawian smallholder agriculture. Journal of Development Studies, 35, pp. 141-161, 1999. 